УДК 35.088.6

DOI: $10.34132 /$ pard2020.10.10

\title{
РЕАЛІЗАЦІЯ КОНЦЕПЦІЇ НАВЧАННЯ ПРОТЯГОМ ЖИТТЯ В УПРАВЛІННІ ПЕРСОНАЛОМ НА ПУБЛІЧНІЙ СЛУЖБІ: ДЕЯКІ ТЕОРЕТИЧНІ АСПЕКТИ
}

Сальніков $\boldsymbol{O}$. O., начальник, Територіальне управління Державної судової адміністрації України в Миколаївській області, аспірант Інститут державного управління, Чорноморський національний університет імені Петра Могили, м. Миколаїв, Україна.

Козлова Л. В., канд. наук 3 держ. упр., доцент, Інститут державного управління, Чорноморський національний університет імені Петра Могили, м. Миколаїв, Україна.

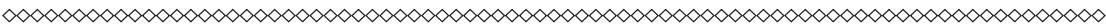

Стаття присвячена розгляду теоретичних засад та практичних можливостей щуодо запровадження концепції навчання протягом життя в діяльність з управління персоналом органів публічної влади. Увага зосереджена також на зарубіжному досвіді та визначенні основних принципів цієї конщепції, ї̈ актуальності для вітчизняноїсистеми публічного управління. В статті визначаються основні поняття $і$ терміни, систематизовані наукової погляди щзодо тлумачення основних понять. Увага приділяється різним віковим групам службовців та прачівників та визначається, щуо зазначена кониепція пропонує достатньо широкий спектр заходів щзодо самореалізачії та просування кар 'єрними сходами. Найбільше уваги приділясться ролі навчання протягом життя в сучасних умовах глобалізачійного розвитку та державного регулювання в иій сфері, оскільки зарубіжний досвід демонструє високі темпи удосконалення освіти в своӥх краӥнах, щчо пов'язано х посиленням системи підвищення кваліфікації $i$ створенням умов для повноцінного розвитку особистості під час виконання професійних завдань та функиій. 
Ключові слова: концепиія навчання протягом життя, управління персоналом, освіта дорослих, органи публічної влади, державні службовиі.

Постановка проблеми у загальному вигляді. Наш світ безперервно змінюється внаслідок творчої та економічної діяльності як окремих людей, так і великих груп, які утворюють людський соціум. В умовах інформаційного соціуму досягнення життєвого успіху людини неможливе без постійного освоєння нових знань, без вдосконалення навичок і компетенцій, які будуть сприяти формуванню творчої особистості, яка вміє не тільки самостійно та критично переосмислювати існуючі виклики повсякденної праці, а формувати нові рішення. Кожна особистість на сучасному етапі розвитку професійної освіти та самореалізації в професійній діяльності все ж таки стикається 3 тим, що відчувається брак певних знань, тому постає необхідність в пошуках нових знань та шляхах і ресурсах щодо їх оновлення. Принцип «освіта через усе життя» реалізується в усіх сферах професійної діяльності в усіх високорозвинених країнах і увага освіті дорослими перебуває в особливому полі зору держави та державної політики щодо створення умов для освіти публічних службовців. Професійну перепідготовку і підвищення кваліфікації намагаються отримати як професійно успішні люди, так і громадяни, які перебувають у пошуках своєї роботи, які стикнулися 3 такими проблемами через неможливість працевлаштування або відсутності необхідної кваліфікації.

Аналіз останніх досліджень і публікацій. До питань щодо запровадження неперервної освіти протягом життя особистості завжди було приділено окрему увагу з боку таких вітчизняних науковців, як Ф. Ващук, Д. Дзвінчук, В. Журавський, О. Кашуба, Б. Клименко, К. Ковальська, В. Кремень, Н. Москаленко, Н. Ничкало, В. Олійник, Т. Пахомова, Н. Семенюк, Л. Товажнянський, О. Щербак. Серед зарубіжних науковців слід відзначити вчених П. Альхайта, А. Гартунга, Е. Грубера, К. Хоул та ін.

Формулювання цілей статті (постановка завдання). Метою статті є дослідження особливостей концепції навчання 
протягом життя як одного 3 напрямів удосконалення професійних компетентностей персоналу органів публічного управління.

Виклад основного матеріалу дослідження. На сонові соціологічних досліджень модна зробити висновки, що в сучасних умовах число людей, що продовжують освіту і опановують нові для них професії і кваліфікації., постійно зростає. Це обумовлюється декількома вагомими причинами: застарівають професійні знання достатньо швидко; популярні в минулому професії стають нецікавими та незатребуваними на ринку праці; людина починає втрачати інтерес до своєї професії або стикається з професійним вигоранням; спеціаліст намагається підвищити свої знання в професійному плані і управляти власною кар'єрою; особистість намагається зробити себе більш конкурентоздатним на ринку праці завдяки отриманню додаткової спеціальності або спеціалізації, підвищити кваліфікацію.

Протягом останніх років достатньо швидко змінилася система оновлення та передачі знань, обсяги знань також значно зросли. Крім того, безперервна освіта стає одним 3 важливих чинників пріоритетності в професіоналізації, інтеграції та пов’язаного 3 цими процесами спільного визнання дипломів, i в цілому поява такої концепції як «освіта впродовж життя» сприяє об’єднанню людства, надаючи нових ціннісних орієнтирів. При цьому важливим фактором $є$ забезпечення безперервності освіти у сучасному культурно-освітньому контексті, що виступає як ідея, принцип навчання та чинники становлення професіонала фахівця. Досвід свідчить, що в сучасному світі ми не можемо отримати освіту раз і на все життя, як це було у минулих поколінь, навіть за 5 років не можна підготувати людину до професійної діяльності, не оновлюючи знань чи не проходячи підвищення кваліфікації протягом життя. Наукові дослідження свідчать, що на сучасному етапі щорічно оновлюється близько 5 \% теоретичних та понад 20 \% професійних знань. Наприклад, одиниця виміру старіння знань фахівця, яка прийнята у США, визначає так званий період напіврозпаду компетентності, що можна трактувати як зниження iii на 50 \% через оновлення інформації з професійної діяльності як 
один з виявів інформаційного суспільства, при цьому це стосується дуже багато професій і цей період менш, ніж через 5 років. Таким чином, стосовно нашої системи вищої освіти компетентність стає неактуальною часто раніше, ніж закінчується навчання.

Вирішення цієї та інших проблем з формування професійних компетентностей пов'язано з переходом до інноваційної концепції, яка відповідає вимогам часу - освіти протягом життя. Згідно цієї концепції базова освіта має бути організована як основа, фундамент для подальшого розвитку і повинна доповнюватися програмами додатковоїосвітиперіодично,взалежностівідфакторуінформаційних змін та суспільного розвитку, змін соціально-економічного розвитку держави. Це проектується на визначення рівнів знань випускників сучасних вишів та визначення професійних компетентностей для більшості спеціальностей. Водночас існують показники, які засвідчують, що студенти в сучасних умовах окрім отриманих знань у вузькій професії мають ще протягом навчання розвивати свої здатності до навчання, навички комунікації, самовдосконалення, адаптивності, організаційної й групової ефективності та інші якості, які будуть визначати успішність особистості в професійному зростанні в інформаційному суспільстві.

Такий принцип «навчання впродовж життя» діє в усіх розвинутих країнах, оскільки в умовах інформаційного суспільства кожна людина так чи інакше стикається з відчуттям недостатності професійних знань, тому відчуває потребу в їх оновленні. I чим швидше відбуваються зміни в інформаційному суспільстві, тим швидше зростають такі потреби та запити.

Кількість людей, які продовжують освіту або освоюють нові професії, постійно зростає. Це визначається такими причинами: наявні професійні знання поступово застарівають; популярні раніше професії стають не конкурентоздатними на ринку праці; також людина може втратити інтерес до тієї професії, якою вона займалася, або відчувається необхідність в підвищенні якості професійних знань.

Тому особистості державного службовця також необхідно постійно отримувати все нові й нові знання, підвищувати свій 
освітній капітал. Категорія державних службовців, як й інші соціальні групи також залучається до концепції безперервної освіти, що базується на ідеї навчання впродовж життя.

Останні роки концепція навчання впродовж життя стала визначальним елементом у стратегіях $\mathrm{CC}$, які мають відношення до формування конкурентоспроможного і динамічного суспільства, де головну роль відіграють знання та професійні цінності. Наприклад, навчання протягом життя було покладено в основу Свропейської стратегії працевлаштування.

В досліджуваній сфері з метою визначення безперервної освіти використовується декілька понять та термінів. У сучасній літературі «можна зустріти такі стійкі сполучення, як «освіта дорослих» (adult education); «продовжена освіта» (continuing education); «подальша освіта» (further education); «відновлювана освіта» (recurrent education) як освіта протягом всього життя шляхом чергування навчання з іншими видами діяльності, головним чином з роботою; «перманентна освіта» (permanent education); «освіта протягом життя» (lifelong education); «навчання протягом життя» (lifelong learning LLL)» [8, c. 21].

Кожне із зазначених понять акцентує увагу на певному боці цього явища, але в цілому основним посилом є довічна незавершеність освіти для дорослої людини. Проблему безперервної освіти умовно поділяють на дві сфери: перша стосується розбудови системи безперервної освіти як частини соціального життя (соціальноосвітній аспект безперервної освіти), друга пов'язана 3 власне процесом засвоєння людиною нового професійного, соціального, а відтак й життєвого досвіду.

Концепція LLL 3 часом змінювалась внаслідок поглиблення досліджень та інтерпретацій понять та явищ в цій царині. У 19701980-х роках «безперервна освіта була орієнтована на надання непривілейованим верствам населення можливості зміни свого статусу за рахунок підвищення освітнього рівня» $[15$, с. 100]. На початку 2000-х років «освіта протягом життя розглядалася переважно як засіб адаптації трудових ресурсів до швидких технологічних змін. Сьогодні в концепції LLL посилюються мотиви особистісного 
зростання» [20]. Одне з соціальних досліджень цієї теми в країнах ЄС показало, що «серед громадян країн $Є С 70$ \% опитуваних людей виявили бажання вчитися, при цьому 80 \% вважають, що освіта має покращити їх професійне життя, а $72 \%$ - особисте» [20].

Отже, можемо надати таке визначення, що неперервна освіта являє собою певний процес, що складається з базової та додаткової подальшої освіти, вона пов'язана 3 наступним послідовним чергуванням навчання 3 професійною діяльністю, при цьому для навчання має бути створена система професійного навчання 3 відповідними освітніми закладами.

Як зазначають науковці, «процес формування особистості у системі неперервної освіти складається 3 двох основних етапів: базова освіта - підготовче навчання та виховання, що хронологічно передує діяльності індивіда у професійній сфері; післябазова (післядипломна) освіта - подальше навчання та виховання, поєднані з практичною діяльністю у сфері суспільного виробництва» [16, с. 6].

Метою неперервної освіти визначено становлення та розвиток особистості в різні періоди іiі життя, починаючи 3 часу фізичного та соціально-психологічного становлення людини, розквіту й стабілізації життєвих сил та усталення цінностей, і закінчуючи часом старіння, коли на перший план постають проблеми збереження життєвих сил та можливостей [16, с. 6].

Системотвірним фактором неперервної освіти $є$ суспільна потреба у постійному розвитку особистості кожної людини. Цим визначається впорядкування безлічі освітніх структур - основних i паралельних, базових і додаткових, державних і громадських (суспільних), формальних і неформальних. Їхній взаємозв〉язок та взаємозумовленість, взаємна субординація за рівнями, координація за спрямованістю і призначенням, забезпечення взаємодії між ними перетворюють всю сукупність таких структур в єдину систему [18].

Єдність цілей неперервної освіти і специфічних завдань кожної iii ланки органічно поєднуються з їі варіативністю, різноманітністю типів освітніх закладів, педагогічних технологій та форм державносуспільного управління. 
Як зазначено в роботі, «неперервна освіта - це сукупність засобів, способів і форм здобуття, поглиблення й розширення загальної освіти, професійної компетентності, культури, виховання, громадянської і моральної зрілості» [18]. Для кожної людини неперервна освіта $\epsilon$ процесом формування й задоволення піi пізнавальних запитів та духовних потреб, розвитку задатків та здібностей у мережі державно-суспільних навчальних закладів i шляхом самоосвіти.

3 позицій державного управління, неперервна освіта $є$ провідною сферою соціальної політики із забезпечення сприятливих умов загального й професійного розвитку кожної особистості. Для суспільства в цілому неперервна освіта $є$ механізмом розширеного відтворення його професійного та культурного потенціалу, умовою розвитку суспільного виробництва, прискорення соціальноекономічного прогресу країни [19].

Для більшості країн та суспільств у світі неперервна освіта $€$ певним способом збереження, розвитку і взаємозбагачення національних культур, слугує для збереження загальнолюдських цінностей, висапує чинником для міжнародної співпраці з метою розв>язання спільних гострих проблем, що постають в сучасному світі.

У світовій педагогіці поняття «неперервна освіта» виражається низкою термінів, серед яких «освіта, що продовжується», «перманентна освіта» та ін. 3 поняттям «неперервна освіта» тісно пов язане поняття «освіта, що поновлюється» [1, с. 117]. Це означає здобуття освіти «частинами» протягом усього життя, відхід від практики тривалого навчання в навчальному закладі, чергування освіти з іншими видами діяльності.

Водночас 3 цим поняттям вживаються й синонімічні терміни, як от: «освіта протягом усього життя» (англ. lifelong education), «продовжена освіта» (англ. continuing education). Деякі автори доцільною вважають «рекурентну (що повторюється час від часу) освіту» (англ. recurrent education) [3, с. 201].

Також в дослідженнях про освіту дорослих зустрічаються терміни, які підкреслюють іiі відносну незалежність від структур формальної освіти, і тому вони визначаються як «освіта поза 
школою» (англ. out-ofschool education) та «неформальна освіта» (англ. non-formal education) [5, с. 12].

Тим не менш, найчастіше під навчанням упродовж життя розуміють всю діяльність як держави, так і окремої людини 3 отримання освіти 3 раннього дитинства аж до пенсії 3 метою самореалізації в процесі досягнення життєвого успіху.

Безперервна освіта - це сукупність способів і форм здобуття, поглиблення та розширення базової освіти, професійної компетентності і культури особистості [6, с. 25]. Для кожної людини безперервна освіта $€$ процесом формування та задоволення iii пізнавальних і духовних потреб, розвитку здібностей у мережі навчальних закладів чи шляхом самоосвіти.

Необхідно зазначити, що в системі безперервної освіти велике значення має об'єкт дослідження - удосконалення компетеностей особистості. Серед професійної компетентності і культури особистості в усій різноманітності інформації та навичок, якими володіють різні спеціалісти, можна виокремити три сфери «компетентності», які складають основу професійної діяльності: спеціальну, міжособистісну, концептуальну.

Спеціальні знання стосуються конкретної функціональної сфери діяльності (економіки, психології, педагогіки та ін.). До них належить і володіння конкретними методами аналізу.

Міжособистісна сфера - це здатність до роботи 3 людьми, відповідні знання, вміння та навички [11, с. 338].

Концептуальна сфера охоплює методологію аналізу і вирішення проблем з урахуванням широкого соціально-економічного контексту, здатність передбачати розвиток економічної та політичної ситуації $[11$, с. 338$]$.

Однак, на думку деяких учених, неперервна освіта в сучасному iii вияві не повинна розглядатися лише 3 позицій чинної освітньої системи і бути обмеженою тільки освітою для дорослих [4, с. 22]. Мова має йти як про удосконалення вже отриманої базової освіти та усунення певних недоліків чи прогалин, так й про адаптацію до професійної діяльності спеціалістів та фахівців в різних видах народного господарства та економіки України. 
Завдання 3 продовженої освіти є достатньо складними та важливими та на сьогодні вирішуються шляхом організації системи підвищення кваліфікації та перепідготовки кадрів, яка є традиційним в нашій країні системоутворюючим складником єдиної системи освіти. Наразі одним 3 важливих завдань неперервної освіти постає забезпечення умов для всебічного гармонійного розвитку особистості та професіонала, на які не повинні впливати такі показники, як вік, здобута раніше професія або спеціальність, місце проживання та інші показники, але очевидно, що така система маж передбачати та грунтуватися на таких показниках як індивідуальні риси та якості особистості, мотиви, інтереси, ціннісні орієнтації та життєві настанови [4, с. 22].

Таким чином, метою неперервної освіти визначається розвиток особистості як в роки їі фізичного і соціально-психологічного становлення та розквіту, так й стабільного стану у реалізації власних здібностей та життєвих цілей, а також охоплює етап фізичного старіння організму людини, коли актуальними постають завдання iз забезпечення життєвих функцій та можливостей, які поступово втрачаються.

Принцип «навчання впродовж життя» на сьогодні вивчається та впроваджується в освітню галузь практично в усіх розвинутих країнах, на це безпосередньо впливає постійний динамічний розвиток інформаційного соціуму, в якому кожна особистість так чи інакше може відчути певний брак знань та потребу в їх оновленні або отриманні додаткових професійних знань чи знань із саморозвитку та адаптації до нових умов життя.

Кількість людей, які намагаються продовжувати здобувати освіту і засвоюють нові професії або підвищують кваліфікацію, постійно зростає. Як визначають деякі науковці, «основними шляхами реалізації програми безперервної освіти є забезпечення наступності змісту та координації навчальної діяльності на різних етапах освіти, що є продовженням попередніх; формування потреби й здатності особистості до самонавчання; оптимізація системи перепідготовки працівників і підвищення їх кваліфікації; створення інтегрованих навчальних планів та програм; запровадження i 
розвиток дистанційної освіти; формування системи навчальних закладів для забезпечення освіти дорослих відповідно до потреб особистості та вимог ринку праці» [14, с. 56].

Запровадження концепції навчання впродовж життя в практичну діяльність державних службовців сприяє в професійному розвитку особистості та визначає іiі адаптацію до динамічно змінюваних умова соціально-економічного розвитку, підвищує можливості уникати соціальної напруженості та досягати життєвого успіху. Безперервна освіта і самоосвіта $є$ потужними чинниками в побудові та управлінні кар'єрою особистості.

Перспективи управління кар'єрою та підвищення службовими сходинами визначаються рівнем професійних знань. умінь та навичок, а також пов'язані із здатністю їх застосовувати на практиці. Усі роботодавці зацікавлені в пошуку найбільш професійних співробітників та висококваліфікованих кадрів, тому цілком логічно, що усі співробітники мають право на професійну підготовку, перепідготовку і підвищення кваліфікації. Саме для цього функціонує системи такої освіти та професійного навчання. Наразі навчання протягом життя це не просто концепція, а практичний вияв одного зі шляхів професіоналізації публічних службовців.

Система такої освіти є корисною та прийнятною на сучасному етапі як найбільш адекватна сучасним вимогам розвитку соціуму, оскільки вона виявляється також механізмом для розвитку професійного потенціалу особистості, іiі культурного та духовного становлення, що в загальному контексті позначається позитивно на соціально-економічному розвитку суспільства, сприяє прискоренню прогресивного шляху держави.

Люди, які не орієнтовані на постійний саморозвиток через навчання, 3 часом втрачають здатність ефективно діяти [12, c. 220]. Водночас, якщо особистість присвячує свій вільний час самоосвіті та саморозвитку, збільшенню освітнього капіталу, наполегливо долаючи всі перешкоди на своєму шляху, то вона обов'язково досягне життєвого успіху. Тому навчання впродовж життя $є$ необхідною умовою самореалізації людини в процесі 
досягнення успіху. Це завдання є важливим не тільки для окремої людини, а й для динамічного розвитку суспільства, підтримки конкурентоспроможності економіки країни, якій потрібні компетентні і високоосвічені громадяни [12, с. 220].

Освіта повинна формувати демократичні основи і критерії життєтворчого процесу, а також почуття власної гідності особистості, сприяти соціальній однорідності суспільства, підвищувати демократичну культуру та соціальну справедливість.

У демократичній, зі сформованими громадськими інститутами державі тільки особистість, яка досягла життєвого успіху, сповідує принцип єдності знань, переконань і діяльності та перебуває в гармонії з собою і світом. У той же час глобалізація, трансформаційні процеси та постійний потік нової інформації обумовлюють включення людини в дуже складну систему суспільних взаємовідносин, вимагають від неї здатності до нестандартних i швидких рішень, творення нових фреймів життєдіяльності до того, як норма інтеріоризується. Тому в країнах Заходу відбувається постійне збільшення інвестицій у галузь освіти, надання спеціальних грантів, оновлення спектра освітніх послуг та технологій для того, щоб створити умови для навчання особистості протягом усього життя [2, с. 31].

Н. Ничкало зазначає, що неперервність професійної освіти, як світова тенденція, формується у другій половині ХХ ст. [13, c. 47] Саме в цей період посилилася тенденція до міжнародного співробітництва в галузі професійної освіти. Насамперед йдеться про широку діяльність ООН, ЮНЕСКО, Міжнародної організації праці (МОП), які ухвалили документи 3 проблем професійного навчання різних категорій населення:

$\checkmark$ у 1962 році Генеральна конференція Міжнародної організації праці на 46-й сесії ухвалила Рекомендацію щодо професійного навчання. У цьому документі чітко обгрунтовується потреба в неперервності професійного навчання, що відповідно закріплено у спеціально сформульованому принципі: навчання є процесом, який триває протягом усього трудового життя людини відповідно до іï потреб як індивіда і члена суспільства; 
$\checkmark$ у 1974 році Генеральна конференція ООН з питань освіти, науки і культури ухвалила Рекомендації щодо професійного i технічного навчання;

$\checkmark$ у 1975 році Генеральна конференція МОП ухвалила Конвенцію про професійну орієнтацію та професійну підготовку в галузі розвитку людських ресурсів та Рекомендаціїщодо професійної орієнтації і професійної підготовки в галузі людських ресурсів;

$\checkmark$ у 1976 році Генеральна конференція ООН з питань науки, освіти і культури на 19-й конференції прийняла Рекомендації про розвиток освіти дорослих;

$\checkmark$ у 1989 році Генеральна конференція ООН з питань науки, освіти і культури ухвалила Конвенцію про технічну і професійну освіту;

у 1997 році Генеральна конференція ЮНЕСКО ухвалює резолюції щодо двох програм «Освіта для всіх протягом усього життя» та «Реформа освіти в перспективі освіти протягом життя»;

$\checkmark$ у 1999 році Другий Міжнародний конгрес ЮНЕСКО 3 технічної і професійної освіти «Освіта і підготовка усього життя: шляхопровід у майбутнє» ухвалив Рекомендації Генеральному директору ЮНЕСКО «Технічна та професійна освіта і навчання: погляд для XXI століття» [13, с. 47].

У цих та інших документах міжнародних організацій концептуально спрогнозовано, на думку українських учених, підходи до розв'язання проблем професійної освіти з урахуванням тенденцій у світовому економічному розвитку: «Враховуючи необхідність нових взаємозв'язків між освітою, трудовим життям і суспільством у цілому, технічна і професійна освіта має існувати як частини системи неперервної освіти, пристосована до потреб кожної країни» [9, с. 38].

Ще у 1996 році міністри освіти країн ОЕСР прийшли до розуміння та визнання, що у XXI сторіччі освіта протягом життя має стати надзвичайно важливою складовою професіоналізації усіх галузей та стабілізації економічних криз, які достатньо негативно позначаються на розвитку суспільств та держав. Вони також визнали, що така освіта повинна бути доступною для всіх 
[10, с. 187]. Тому нові підходи зумовили формування політик в розвинутих державах, що визначали напрями реформування власних систем освіти. Це було початком фундаментальних змін у навчальних програмах та підходах до професіоналізації освіти, створення належних умов для самомотивації до постійного підвищення рівня освіти [10, с. 187].

Помітне посилення уваги до проблем неперервної освіти в багатьох зарубіжних країнах у другій половині XX століття зумовлено стрімким розвитком науково-технічної революції [7, с. 15]. Після Другої світової війни політика в галузі освіти в індустріально розвинутих країнах, у тому числі в західноєвропейських, спрямовувалася на забезпечення підготовки i вдосконалення виробничого персоналу [7, с. 15]. У зв'язку з цим розвивалися різні організаційно-педагогічні форми продовження освіти поза загальноосвітніми школами (наприклад, на виробництві - різні курси, школи, навчально-професійні майстерні, професійні центри, а також у галузевих інститутах підвищення кваліфікаціі).

Таким чином, початок XXI століття позначився усвідомленням вироблення нових підходів до системи освіти таїі складової-системи підвищення кваліфікації, відбулася подальша широкомасштабна модернізація, що також пов'язано і 3 процесами інтеграції на європейському континенті. Внаслідок цих кроків, у березні 2000 року Лісабонський саміт Ради Європи погодив «Меморандум освіти протягом життя» (A Memorandum of Lifelong Learning) [21].

В цьому документи визначається, що безперервна освіта повинна стати важливим елементом та частиною політичних програм для громадянського суспільства, сприяти його соціальній єдності. Безперервна освіти грунтується на таких складових, як отримання професійних ступенів та дипломів, відвідування професійних курсів та курсів з підвищення кваліфікації або перекваліфікації, друга вища освіта та освіта дорослих.

Також у Меморандумі йдеться про такі основні принципи освіти протягом життя: нові базові знання і навички для всіх, збільшення інвестицій в людські ресурси, інноваційні методики викладання й навчання, нова система оцінки отриманої освіти, 
розвиток наставництва й консультування, наближення освіти до місця проживання [21].

Отримання нових базових знань та навичок для всіх повинно бути забезпечено загальним безперервним доступом до освіти i гарантувати саме такі знання, які сприятимуть людині в існуванні в інформаційному суспільстві. Відповідно до документів Лісабонського саміту до таких видів знань увійшли комп'ютерна грамотність, технологічна та інформаційна культура, іноземні мови, підприємницькі навички та навички соціалізації.

Збільшення інвестицій в людські ресурси пов'язано 3 необхідністю посилення конкурентоспроможності людей на ринку праці в країнах $\mathrm{CC}$, і в цілому спрямовано на посилення пріоритетів СС щодо розвитку та збереження людського потенціалу на європейському континенті. В останніх документах $\mathrm{CC}$ було наголошено про необхідність збільшувати інвестиції в людські ресурси, активізуючи методи соціального партнерства і досвід провідних підприємств.

Інноваційніметодинавчанняпов'язанізнеобхідністювироблення нових форм та методології навчання, які були б найбільш відповідні системі освіти протягом життя. Інформаційне суспільство пов'язано 3 викликами, але водночас й надає розмаїття освітніх інструментів, які сприяють адаптації особистості в сучасному суспільстві та світі. Методи навчання у формальній та неформальній системі освіти грунтуються на орієнтації на споживача освітніх послуг і повинні оновлюватися у відповідності до суспільних запитів, що пов'язано 3 розвитком мотивації особистості, здатності до навчання та мислити критично.

Також докорінних змін зазнала й система оцінки, оскільки змінилися підходи до розуміння і визнання навчальної діяльності та iii результатів, особливо ці питання набули важливості для інформальної та неформальної освіти. Постала необхідність у визнанні такої освіти та їі ролі в системі освіти протягом життя. Тому було розроблено якісно нову систему оцінки «Акредитації попередньої і неформальної освіти» (Accreditation of Prior and Experiential Learning - APEL). 
Розвиток наставництва та консультування пов>язаний iз необхідністю забезпечення будь-якій особистості вільний доступ до інформації про освітні можливості. Постала також необхідність в країнах ЄС у створенні постійної консультаційної служби, яка займалася б питаннями консультування у сфері освітнього, професійного та особистісного розвитку і забезпечувала б інтереси та потреби людини, що прагне до навчання.

Важливим в такій системі освіти виявився й територіальний чинник, оскільки було визначено, що людина не повинна бути змушена залишати своє місце проживання для отримання якісної освіти або підвищення кваліфікації і система безперервної освіти має забезпечуватися мережею навчальних та консультаційних пунктів, відповідними інформаційними ресурсами, особливо в умовах дистанційної освіти. Водночас, освіта протягом життя не виключає свободу вільного вибору та пересування.

Таким чином, освіта протягом життя стала складовим механізмом системи освіти та освітніх послуг. Як зазначається, на сучасному етапі розвитку системи освіти розмежовано три основні форми освіти, що відображено в таблиці 1.

Цілі, які визначаються та реалізуються в системі неперервної освіти, умовно розмежовують також на такі три складові, що відображено на рисунку 1 .

Додаткова професійна освіта має сприяти формуванню професійної основи кадрового потенціалу сучасної високотехнологічної економіки. Споживачами послуг даної частини системи неперервної освіти $€$ соціально адаптована частина населення, яка отримує освіту послідовно на всіх їі рівнях).

Забезпечення різноманітним групам населення можливостей для адаптації умов життя, що змінюються. Така підсистема має на меті освіту, що спрямована на адаптацію й реабілітацію соціальних і професійних груп, які не здатні пристосуватися до швидкозмінного соціального середовища самостійно. До цієї підсистеми залучаються громадяни, які виявилися обмежені з різних причин у доступі до формальної системи професійної освіти, що є загрозою до десоціалізації. 


\section{Три основні форми сучасної освіти [23]}

\begin{tabular}{|c|c|}
\hline Назва освіти & Зміст \\
\hline $\begin{array}{c}\text { формальна } \\
\text { освіта }\end{array}$ & $\begin{array}{l}\text { початкова, загальна середня освіта, середня професійна } \\
\text { освіта, вища освіта, освіта після закінчення ВНЗ } \\
\text { (аспірантура й докторантура), підвищення кваліфікації } \\
\text { й перепідготовка фахівців і керівників з вищою і } \\
\text { середньою професійною освітою в інститутах, на } \\
\text { факультетах і курсах підвищення кваліфікації й } \\
\text { професійної перепідготовки }\end{array}$ \\
\hline $\begin{array}{c}\text { неформальна } \\
\text { освіта }\end{array}$ & $\begin{array}{l}\text { професійно спрямовані й загальнокультурні курси } \\
\text { навчання в центрах освіти дорослих, на різних курсах } \\
\text { інтенсивного навчання }\end{array}$ \\
\hline $\begin{array}{c}\text { інформальна } \\
\text { освіта }\end{array}$ & $\begin{array}{l}\text { індивідуальна пізнавальна діяльність, що супроводжує } \\
\text { повсякденне життя, реалізується за рахунок власної } \\
\text { активностііндивідів в оточуючому культурно-освітньому } \\
\text { середовищі; спілкування, читання, відвідування установ } \\
\text { культури, подорожі, засоби масової інформації тощо. } \\
\text { При цьому людина перетворює освітні потенціали } \\
\text { суспільства в дієві чинники свого розвитку }\end{array}$ \\
\hline $\begin{array}{l}\text { даткова профе } \\
\text { освіта }\end{array}$ & $\begin{array}{c}\text { Забезпечення } \\
\text { різноманітним групам } \\
\text { населення можливостей } \\
\text { для адаптапії умов життя, } \\
\text { що змінюються }\end{array}$ \\
\hline
\end{tabular}

Puc.1. Система неперервної освіти в країнах СС (основні підсистеми)

Третя складова системи освіти дорослих в ЄС забезпечує задоволення різноманітних індивідуальних освітніх потреб громадян (мовну підготовку, отримання психологічних, культурноетичних та інших знань, комунікативних навичок, спеціальних умінь тощо) [17, с. 11]. 
Окрім формалізованих структур додаткової професійної освіти до системи освіти входять й підсистеми неформальних структур, наприклад, різноманітні тренінги, вебінари, майстер-класи, система перепідготовки та навчання на підприємствах та компаніях, які можуть здійснювати підготовку як на основі формалізованих освітніх закладів та ресурсів, так і можуть створюватися неформально, але, як свідчить практика, на короткий термін. До складових компонентів цієї системи входить освіта в різних іiі формах та дистанційна освіта [22, с. 32].

Слід зазначити, що з часу запровадження освіти впродовж життя значно зросли суспільні запити різних соціальних груп на отримання таких освітніх послуг, оскільки дійсно виявляється неможливим їх задовольнити в рамках традиційної освіти. Посилюється проблема невідповідності системи освіти новим суспільним запитам, що пов'язано 3 іншим можливим напрямом удосконалення надання освітніх послуг та реалізації концепції навчання протягом життя - навчання повинне відповідати різноманітним інтересам і можливостям громадян, їхньому способу життя, враховувати специфіку різних суспільних запитів.

Наразі безперервна освіта почала ототожнюватися не тільки як «навчання протягом життя» (lifelong learning), а й як «навчання шириною в життя» (lifewide learning). Вважається, що таке визначення охоплює зміст усіх трьох підсистем освіти протягом життя - формальну, неформальну та інформальну [23].

При дослідженні зазначеної слід акцентувати увагу також на такому факторі, що при формуванні державної політики в сфері забезпечення освіти протягом життя, така освіти може плануватися «зверху», адміністративними методами, але для того, щоб бути дійсно ефективною, вона має враховувати суспільні запити, які йдуть від спеціалістів, працівників, соціальних професійних груп та роботодавців. Неформальна освіта безпосередньо відображає й задовольняє особистісні потреби й запити людини, мотивуючи до самоосвіти та самовдосконалення, внутрішнього емоційного та професійного зростання. Таким чином, удосконалення системи неформальної освіти може сприяти створенню умов для самореалізації людини та громадянина, морального задоволення за рахунок надання 
більш ширших можливостей щодо обрання напрямів освіти та форм надання освітніх послуг та освітнього процесу.

Висновки. Здобуття знань, умінь та компетенції має носити постійний характер i здійснюватися починаючи 3 дитинства i до пенсійного віку. У такому суспільстві життєдіяльність особистості може бути успішною лише за умови постійного засвоєння інноваційних ідей, що можливо тільки в результаті самостійного навчання протягом усього життя. Причому специфіка сучасного інформаційного суспільства полягає в тому, що людині необхідно спрямовувати своє навчання на засвоєння тих знань, що будуть затребувані у майбутньому.

В умовах прискореного розвитку інформаційного суспільства бути виконавцем, який вміє добре засвоювати рамки вже існуючих взаємодій, означає тільки одне - все життя залишатися підлеглим.

Для того, щоб зробити успішну кар'єру, людині вже сьогодні слід перейти до самовизначення цілей, цінностей, якостей, знань, вмінь та навичок, що будуть визначати iї життєвий успіх у майбутньому. Крім того, важливою передумовою досягнення життєвого успіху особистості стає формування гнучкого, емоційного інтелекту, який дозволить не тільки адекватно сприймати мінливий світ, а й формувати рамки майбутніх взаємодій, відчувати, як світ буде змінюватися і що треба зробити вже сьогодні для того, щоб бути успішним завтра. Це допоможе людині вийти за межі стандартних знань, усталених істин та створити щось нове.

Стереотипне мислення, яке базується тільки на пасивному засвоєнні вже існуючих у суспільстві обмежень, не дозволить стати успішною особистістю в умовах світу, що змінюється майже щодня.

Таким чином, проведений аналіз дозволяє зробити висновок, що в умовах сучасного інформаційного суспільства досягнення життєвого успіху людини неможливе без постійного поповнення освітнього капіталу. Безперервне отримання нових знань та навичок буде сприяти формуванню творчої особистості, яка вміє ефективно адаптуватися до нових умов життєдіяльності, здатна критично мислити, самостійно ставити і ефективно досягати життєві цілі.

\section{Стаття надійшла до редакції: 11.10.20}




\section{IMPLEMENTATION OF THE CONCEPT OF LIFELONG LEARNING IN PERSONNEL MANAGEMENT IN THE PUBLIC SERVICE: SOME THEORETICAL ASPECTS}

Oleksiy Salnikov, Territorial Department of the State Judicial Administration of Ukraine in the Mykolaiv region, Mykolaiv, Ukraine.

Kozlova Liudmyla, Associated Professor PhD in Public Administration of the Institute of Public Administration of the Black Sea National Petro Mohyla University, Mykolaiv, Ukraine.

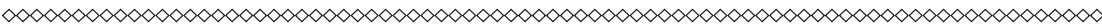

The article is devoted to the consideration of theoretical principles and practical possibilities for the introduction of the concept of lifelong learning in the management of personnel of public authorities. Attention is also focused on foreign experience and defining the basic principles of this concept, its relevance for the domestic system of public administration. The article defines the basic concepts and terms, systematized scientific views on the interpretation of basic concepts. In the information society, achieving life success is impossible without constant development of new knowledge, without improving skills and competencies that will contribute to the formation of a creative personality that can not only independently and critically rethink existing challenges of daily work, but to form new solutions. Everyone today lacks certain knowledge and needs to update it regularly. The principle of "lifelong learning" applies in all civilized countries. Both professionally successful people and unemployed citizens who have become so due to the impossibility of employment or lack of the necessary qualifications strive for professional retraining and advanced training.

Sociological research shows that in modern conditions the number of people continuing their education and learning new professions and qualifications is growing. This is due to many reasons: the professional knowledge acquired by a person quickly becomes obsolete; once popular professions become unclaimed; the person loses interest in the 
chosen profession; a person seeks to improve the quality of professional knowledge and build a career; a person increases his competitiveness by obtaining an additional specialty or qualification.

In recent decades, the system of knowledge generation and transfer has changed dramatically, and their volume has increased many times over. In the case of the unification of humanity on the basis of certain values and goals, of course, one of the priority factors is continuing education. Continuity acts in the modern cultural and educational context as an idea, the principle of learning, the quality of the educational process, the condition of human development. Today it is impossible to prepare a person for professional activity for life at once, even in 5 or 6 years. Scientific research shows that at the present stage about $5 \%$ of theoretical and $20 \%$ of professional knowledge is annually updated. For example, the unit of measurement of specialist knowledge, which is accepted in the United States, determines the period of "half-life" of competence, ie its reduction by 50\% due to new information, shows that in many professions this period occurs in less than 5 years. Thus, for our higher education system, competence often becomes irrelevant before graduation.

Key words: concept of lifelong learning, personnel management, adult education, public authorities, civil servants.

\section{Received: 11.10.20}

\section{References}

1. Andreev, A.L. (2008). Rossyiskoe obrazovanye. Sotsyalnoystorycheskye konteksty [Russian education. Social-historical contexts]. Moskow: Nauka, 2008 [in Russian].

2. Honcharuk, A. Neformalna osvita doroslykh u krainakh YeS [Non-formal adult education in the EU]. Pedahohichni nauky - Pedagogical Sciences, 54, 31-36 [in Ukrainian].

3. Horuk, N. (2010). Istorychni aspekty rozvytku neformalnoi osvity doroslykh u SShA [Historical aspects of non-formal adult education in the United States]. Visnyk Lvivskoho universytetu : [Seriia pedahohichna] - Visnyk of Lviv National University: [Pedagogical series], 26, 201-207 [in Ukrainian]. 
4. Derkach, Yu. (2008). Neformalna osvita yak umova neperervnoho navchannia molodi [Non-formal education as a condition of continuous learning of youth]. Visnyk Lvivskoho universytetu: [Seriia pedahohichna] Visnyk of Lviv National University: [Pedagogical series], 23, 17-22 [in Ukrainian].

5. Desiatov, T.M. (2012). Aktualni problemy osvity doroslykh u konteksti hlobalizatsii [Actual problems of adult education in the context of globalization]. Porivnialna profesiina pedahohika-Comparative professional pedagogy, 1, 6-13 [in Ukrainian].

6. Ievnukh, M.B. \& Voloshchuk, I.S. (2009). Problemy yakosti osvity [Problems of quality of education]. Vyshcha osvita Ukrainy. - Doid.: 1. - Tema. vyp. «Pedahohika i psykholohiia: metodolohiia, teoriia, tekhnolohii»-Higher education of Ukraine. - Doyd .: 1. - Temam. issue "Pedagogy and psychology: methodology, theory, technology», 3. Kyiv: Hnozys [in Ukrainian].

7. Ziaziun, I.A. (2001). Neperervna osvita yak osnova sotsialnoho postupu [Continuing education as the basis of social progress]. Neperervna profesiina osvita: teoriia i praktyka: zb. nauk. prats - Continuing professional education: theory and practice: coll. science. wash, 1, (pp. 15-23). Kyiv. : Vyd. tsentr NTU «KhP» [in Ukrainian].

8. Ziaziun, I.A. (2003). Pedahohichna maisternist u zakladakh profesiinoi osvity : [Monohrafia] [Pedagogical skills in institutions of professional education: [Monograph]]. (N.H. Nychkalo, Trans). Kyiv: APN Ukrainy, In-t pedahohiky i psykholohii prof. osvity [in Ukrainian].

9. Kochubeinyk, O.M. \& Tytarenko, T.M. \& Cheremnykh, K.O. (2014). Psykholohichni praktyky konstruiuvannia zhyttia $v$ umovakh postmodernoi sotsialnosti : monohrafiia [Psychological practices of constructing life in postmodern sociality: monograph]. Natsionalna akademiia pedahohichnykh nauk Ukrainy, Instytut sotsialnoi ta politychnoi psykholohii. Kyiv : Milenium [in Ukrainian].

10. Lukianova, L. (2015). Neperervna osvita vprodovzh zhyttia: istorychnyi ohliad, suchasni realii [Continuing education throughout life: a historical review, modern realities]. Naukovyi visnyk Melitopolskoho derzhavnoho pedahohichnoho universytetu. Seriia : Pedahohika - Scientific Bulletin of Melitopol State Pedagogical University. Series: Pedagogy, 2 (15), 187-192 [in Ukrainian]. 
11. Markozova, O.O. \& Hetman, A.P. (Eds.). (2013). Zmina uiavlen liudei pro uspikh yak naslidok ideolohichnykh vplyviv postmodernizmu [Change of people's ideas about success as a consequence of ideological influences of postmodernism]. Visn. Nats. un-tu "Iuryd. akad. Ukrainy im. Yaroslava Mudroho». Seriia: Filosofiia, filosofiia prava, politolohiia, sotsiolohiia - Visn. Nat. un-tu «Jurid. acad. Of Ukraine named after Yaroslav the Wise «. Series: Philosophy, philosophy of law, political science, sociology, 5 (19), (pp. 338-345). Kharkiv: Pravo [in Ukrainian].

12. Markozova, O.O. \& Hetman, A.P. (Eds.). (2014). Mekhanizm motyvatsii dosiahnennia zhyttievoho uspikhu liudyny [The mechanism of motivation to achieve human success]. Visn. Nats. un-tu «Iuryd. akad. Ukrainy im. Yaroslava Mudroho». Seriia: Filosofiia, filosofiia prava, politolohiia, sotsiolohiia - Visn. Nat. un-tu «Jurid. acad. Of Ukraine named after Yaroslav the Wise «. Series: Philosophy, philosophy of law, political science, sociology, 2 (21), (pp. 214-221). Kharkiv: Pravo [in Ukrainian].

13. Nychkalo, N. \& Levovytskiy, T. \& Ziaziun, I. (Eds.). (2000). Standarty profesiinoi osvity: problemy metodolohii i tvorchykh poshukiv [Standards of professional education: problems of methodology and creative research]. Profesiina osvita: pedahohika $i$ psykholohiia : ukrainsko-polskyi, polskoukrainskyi shchorichnyk - Professional education: pedagogy and psychology: Ukrainian-Polish, Polish-Ukrainian yearbook, 2, (pp. 47-63). Kyiv: Vyd-vo ZAT «Vipol» [in Ukrainian].

14. Parashchuk, O. \& Karpyevych, D. \& Usatenko, H. (2012). Neformalnoe obrazovanye v Ukrayne [Non-formal education in Ukraine]. Neformalnoe obrazovanye dlia rehyonalnykh demokratycheskykh transformatsyi : [Yssledovanye]-Non-formaleducation for regionaldemocratic transformations: [Study]. Kyiv : Fond «Evropa KhKhI» [in Russian].

15. Semeniuk, N. (2012). Bezperervna osvita: svitova praktyka y Ukraina [Continuing education: world practice and Ukraine]. Vyshcha osvita Ukrainy Higher education in Ukraine, 4, 100-105 [in Ukrainian].

16. Tytarenko, T.M. (2010). Postmoderna osobystist u dynamitsi samokonstytuiuvannia [Postmodern personality in the dynamics of self-constitution]. Aktualni problemy psykholohii: Psykholohichna hermenevtyka : zb. nauk. prats - Actual problems of psychology: Psychological hermeneutics: collection. Science. works, (Vols. 2), 6, (pp. 5-14). Kyiv [in Ukrainian]. 
17. Tytov, V.N. (2014). Evoliutsyia i teoretycheskie predposylki stanovlenyia kontseptsyy «obrazovanye $\mathrm{v}$ techenye zhyzny» [Evolution and theoretical prerequisites for the formation of the concept of «education during life»]. Professyonalnoe obrazovanye v Rossyy $i$ za rubezhom - Vocational education in Russia and abroad, 1 (13), 10-19 [in Russian].

18. Tkach, T.V. Rozvytok osobystosti zasobamy neformalnoi osvity [Development of personality by means of non-formal education]. Retrieved from http://ecopsy.com.ua/data/zbirki/2008_15/sb15_72.pdf [in Ukrainian].

19. Tiahusheva, O.H. (2009). Neobkhidnist ta perspektyvy bezperervnosti osvity yak pryntsypu osvitnoi polityky Ukrainy [Necessity and prospects of continuity of education as a principle of educational policy of Ukraine]. Derzhavne rehuliuvannia protsesiv ekonomichnoho i sotsialnoho rozvytku State regulation of economic and social development. Retrieved from http:// www.kbuapa.kharkov.ua/e-book/tpdu/2008-3/doc/3/30.pdf [in Ukrainian].

20. Making a European area of lifelong learning a reality. ec.europa.eu. Retrieved from http://ec.europa.eu/education/ [in English].

21. A Memorandum on Lifelong Learning. arhiv.acs.si. Retrieved from http://arhiv.acs.si/dokumenti/Memorandum_on_Lifelong_Learning.pdf [in English].

22. Parker, B. \& Chummier, H. (1992). Development and validation of a life-success measures scale. Psychological Reports, (Vol. 70) [in English].

23. Towards an institutional strategy for Lifelong Learning in Higher Professional Education. www.aqu.cat. Retrieved from www.aqu.cat/doc/ doc_16974883_1.pdf [in English].

\section{Відомості про авторів / Information about the Authors}

Сальніков Олексій Олександрович: Територіальнеуправління Державної судової адміністрації України в Миколаївській області: вул. Фалєєвська 14, м. Миколаїв, 54001, Україна.

Oleksiy Salnikov: Territorial Department of the State Judicial Administration of Ukraine in the Mykolaiv region: Faleyevskya str. 14, Mykolaiv, 54001, Ukraine. 


\section{ORCID.ORG./ 0000-0002-5612-784X}

\section{E-mail: inbox@mk.court.gov.ua}

Козлова Людмила Василівна: Чорноморський національний університет імені Петра Могили: вул. 68 десантників 10, м. Миколаїв, 54003, Україна.

Liudmyla Kozlova: Black Sea National University of Petro Mohyla: 68 Desantnykiv str. 10, Mykolaiv, 54003, Ukraine.

ORCID. ORG./ 0000-0003-4808-6846

E-mail: kozlovalife@ukr.net 